\title{
Chave de identificação de espécies do estrato arbóreo da Mata Atlântica em Ubatuba (SP), com base em caracteres vegetativos
}

\author{
Mariella Eltink ${ }^{1,6}$, Eliana Ramos ${ }^{2}$, Roseli Buzanelli Torres ${ }^{3}$, Jorge Yoshio Tamashiro ${ }^{4}$, \\ Eduardo Galembeck ${ }^{5}$ \& Eduardo Kimura ${ }^{5}$ \\ ${ }^{1}$ Instituto Agronômico de Campinas, Campinas, SP, Brasil. http://www.iac.sp.gov.br Bolsista CNPq/PIBIC \\ (proc. no. 0800023) e IC/FAPESP (proc. no. 2009/03563-0) \\ ${ }^{2}$ Programa de Pós-Graduação em Ciências Biológicas (Biologia Vegetal), Instituto de Biociências, \\ Universidade Estadual Paulista Júlio de Mesquita Filho - UNESP, \\ CP 199, CEP 13506-900, Rio Claro, SP, Brasil. http://www.rc.unesp.br \\ ${ }^{3}$ Núcleo de P e D Jardim Botânico, Centro de Recursos Genéticos Vegetais, \\ Instituto Agronômico de Campinas, Av. Barão de Itapura, 1481, \\ CEP 13020-902, Campinas, SP, Brasil. http://www.iac.sp.gov.br \\ ${ }^{4}$ Departamento de Biologia Vegetal, Instituto de Biologia, \\ Universidade Estadual de Campinas - UNNICAMP, CP 6109, CEP 13083-970, \\ Campinas, SP, Brasil. http://www.ib.unicamp.br \\ ${ }^{5}$ Departamento de Bioquímica, Instituto de Biologia, Universidade Estadual de Campinas - UNICAMP, \\ CP 6109, CEP 13083-970, Campinas, SP, Brasil. http://www.iac.sp.gov.br \\ ${ }^{6}$ Autor para correspondência: Mariella Eltink,e-mail:m_eltink@hotmail.com
}

ELTINK, M., RAMOS, E., TORRES, R.B., TAMASHIRO, J.Y., GALLEWMBECK, E. \& KIMURA, E. Key for the identification of the arboreal stratum species of the Atlantic Rain Forest in Ubatuba (SP) based on vegetative characters. Biota Neotrop. 11(2): http://www.biotaneotropica.org.br/v11n2/en/abstract?identificationkey+bn02511022011

\begin{abstract}
The identification key was developed taking into account the herbarium specimens from the species of the arboreal stratum sampled, with at least $4.8 \mathrm{~cm} \mathrm{DBH}$, in two stretches of Lower Montane Rain Forest. Only morphological vegetative characters were used, such as phyllotaxy, leaf shape, presence or absence of stipules, trichomes and glands, and other aspects relevant to the species identification, besides field observations. The key comprises 193 (4 without identification) species belonging to 114 genera and 50 botanical families, and an interactive electronic version is available online at the site http://www.gama.ib.unicamp.br/gama/index.php. Keywords: Submontane Rain Forest, Capricórnio Farm, Serra do Mar State Park, floristics.
\end{abstract}

ELTINK, M., RAMOS, E., TORRES, R.B., TAMASHIRO, J.Y., GALLEWMBECK, E. \& KIMURA, E. Chave de identificação de espécies do estrato arbóreo da Mata Atlântica em Ubatuba (SP), com base em caracteres vegetativos. Biota Neotrop. 11(2): http://www.biotaneotropica.org.br/v11n2/pt/abstract?identificationkey+bn02511022011

Resumo: A chave de identificação foi elaborada com base no material herborizado das espécies do estrato arbóreo amostradas com pelo menos 4,8 cm de DAP, em dois trechos de Floresta Ombrófila Densa Submontana. Foram utilizadas apenas características morfológicas vegetativas, como a filotaxia, forma das folhas, presença ou ausência de estípulas, indumento e glândulas, dentre outros aspectos relevantes para a identificação das espécies, e observações de campo. A chave consta de 193 espécies (4 indeterminadas), distribuídas em 114 gêneros e 50 famílias botânicas, e uma versão eletrônica interativa está disponível para consulta on line (http://www.gama. ib.unicamp.br/gama/index.php ).

Palavras-chave: Floresta Ombrófila Densa Submontana, Fazenda Capricórnio, Parque Estadual da Serra do Mar, florística. 


\section{Introdução}

A ausência de espécies em estado fértil é frequente durante a realização de trabalhos com a vegetação nativa. Talora \& Morellato (2000) observam que muitas espécies de árvores da floresta tropical não florescem com frequência. Além disso, as formações nativas caracterizam-se pela alta diversidade de espécies, dificultando a identificação dos táxons, particularmente quando estéreis. Assim, é de grande valia disponibilizar informações mais completas sobre os caracteres vegetativos, pois possibilitam a identificação das espécies em qualquer período do ano, não havendo necessidade da presença de flor e fruto. A preocupação de se elaborar chaves para a identificação das espécies tendo como base características morfológicas vegetativas está presente há certo tempo, tanto para as espécies do cerrado (Mantovani et al. 1985, Batalha et al. 1998), como também para as árvores da Mata Atlântica (Braz et al. 2004, Urbanetz et al. 2010). As chaves de identificação baseadas em caracteres morfológicos são especialmente importantes para os estudos de longo prazo, em parcelas permanentes, de modo que pesquisas em diferentes áreas do conhecimento possam utilizar as informações geradas pelos estudos florísticos.

O presente trabalho teve como objetivo a elaboração de uma chave de identificação baseada em caracteres vegetativos, permitindo a identificação das espécies do estrato arbóreo encontradas em dois trechos de Mata Atlântica, contribuindo, assim, para o conhecimento da florística da área, bem como de outras com o mesmo perfil fisionômico.

\section{Material e Métodos}

O material utilizado na elaboração da chave foi o coletado para os trabalhos de Ramos (2008) e Ramos et al. (2011), no município de Ubatuba, nas terras da Fazenda Capricórnio (100 m s.n.m.) e no Parque Estadual da Serra do Mar (PESM) (200 m s.n.m.), como parte dos estudos florísticos e fitossociológicos do projeto temático Biota Gradiente Funcional (Joly et al. 2011).

As áreas estudadas enquadram-se na categoria de Floresta Ombrófila Densa Submontana (Veloso et al. 1991), com clima regional tropical úmido, sem estação seca, tipo Af sensu Köeppen (1948), com a temperatura média do mês mais quente igual ou superior a $22^{\circ} \mathrm{C}$.

O material testemunho de todas as espécies amostradas, mesmo quando vegetativo, foi incorporado ao acervo do herbário do IAC (http://herbario.iac.sp.gov.br), e as duplicatas enviadas aos herbários das instituições participantes do projeto temático.

A partir dos materiais já identificados, foi elaborada uma diagnose com as principais características morfológicas das espécies, utilizando-se terminologia segundo Radford et al. (1974), Harris e Harris (1994), Vidal \& Vidal (2000) e Gonçalves \& Lorenzi (2007). Na descrição das estruturas observadas, como folhas, pecíolo, ramos, considerou-se sempre as maiores medidas dos materiais coletados, ou seja, das estruturas totalmente desenvolvidas, e o tamanho das plantas foi baseado nas alturas máximas alcançadas pelas espécies nas parcelas. A descrição do padrão de venação das folhas seguiu Radford et al. (1974). As estruturas reprodutivas, flores ou frutos, foram descritas de forma sucinta e complementadas com as anotações feitas em campo e registradas nas fichas das exsicatas. Considerando que algumas espécies ocorrem na área com muitos indivíduos, todos os materiais foram utilizados na elaboração da diagnose, de modo a abranger a sua variabilidade morfológica.

Uma chave interativa, com ilustrações e informações complementares, como a distribuição geográfica das espécies, está disponível no sítio http://www.gama.ib.unicamp.br.

\section{Resultados e Discussão}

A chave de identificação consta de 185 espécies de árvores (4 indeterminadas), 3 de palmeiras e 3 de fetos arborescentes, distribuídos em 114 gêneros e 50 famílias botânicas. Na chave, as espécies estão separadas inicialmente em quatro grupos principais, tendo como base a ausência de ramificações no caule e folhas compostas, Chave 1, que engloba as palmeiras e os fetos arborescentes). Para as árvores, a presença de ramificações na porção aérea e folhas compostas compõem a Chave 2; folhas simples, opostas ou subopostas, Chave 3; ou alternas, Chave 4. No sítio do herbário IAC (http://herbario.iac.sp.gov.br) é possível, através do número de registro, acessar todas as informações de coleta das espécies.

As famílias mais ricas foram Myrtaceae, com 37 espécies; Rubiaceae (17), Fabaceae (16), Lauraceae (10) e Melastomataceae (9). É possível caracterizar e individualizar cada uma das espécies amostradas com base na morfologia externa das extremidades dos ramos e das folhas, mas dependendo da espécie, como as da família Myrtaceae, essa diferenciação é muitas vezes sutil, e exige atenção aos pequenos detalhes como, por exemplo, o tamanho do pecíolo e a distância da venação marginal à margem do limbo. Espécies de outras famílias também reconhecidamente ricas, como Lauraceae, Melastomataceae e Rubiaceae, são difíceis de serem separadas, mas a observação de pequenos detalhes auxilia a sua identificação. Apenas em duas situações espécies de Myrtaceae não puderam ser discriminadas na chave (Eugenia prasina/E. cf. subavenia e Eugenia oblongata/E. aff. oblongata) e nestes casos é necessário comparar novas coletas com os materiais depositados nos herbários. Cordia cf. superba, C. taguahyensis, Guapira cf. hirstua, G. opposita e Sloanea guianensis foram incluídas em mais de uma entrada na chave por apresentarem tanto folhas opostas como subopostas ou mesmo alternas.

Muitas espécies aqui apresentadas ocorrem em outros trechos da floresta (Eisenlohr et al., dados não publicados). Uma vez que houve a padronização das identificações de todos os materiais coletados no âmbito do projeto temático, esta chave poderá ser utilizada também para a identificação de espécies de outras áreas de estudo.

\section{Agradecimentos}

Este trabalho foi parcialmente financiado pela Fundação de Amparo à Pesquisa do Estado de São Paulo (FAPESP) no âmbito do Projeto Temático Biota Gradiente Funcional: Composição florística, estrutura e funcionamento da Floresta Ombrófila Densa dos Núcleos Picinguaba e Santa Virgínia do Parque Estadual da Serra do Mar (Processo 03/12595-7), que faz parte do Programa BIOTA/FAPESP O Instituto Virtual da Biodiversidade (www.biota.org.br). Autorização COTEC/IF 41.065/2005 e autorização IBAMA/CGEN 093/2005. Os autores agradecem ainda ao $\mathrm{CNPq}$ pela bolsa concedida; aos taxonomistas pela confirmação ou identificação dos materiais; aos proprietários da Fazenda Capricórnio pela autorização de trabalhar na área e apoio recebido, e aos auxiliares de campo por toda a ajuda e conhecimento local.

\section{Referências Bibliográficas}

BATAlHA, M.A., ARAGAKI, S. \& MANTOVANI, W. 1998. Chave de identificação das espécies vasculares de cerrado em Emas (Pirassununga, SP) baseada em caracteres vegetativos. Bol. Bot. 17:85-108.

BRAZ, D.M., MOURA, M.V.L.P. \& ROSA, M.M.T. 2004. Chave de identificação para as espécies de dicotiledôneas arbóreas da Reserva Biológica do Tinguá, RJ, com base em caracteres vegetativos. Acta Bot. Bras. 18(2):225-240. http://dx.doi.org/10.1590/S010233062004000200003 
GONÇALVES, E.G. \& LORENZI, H. 2007. Morfologia vegetal: organografia e dicionário de morfologia das plantas vasculares. Instituto Plantarum, Nova Odessa.

HARRIS, J.G. \& HARRIS, M.W. 1994. Plant identification terminology: an illustrate glossary. Spring Lake Publishing, Payson.

JOLY, C.A., ASSIS, M.A., BERNACCI, L.C., TAMASHIRO, J.Y., CAMPOS, M.C.R., GOMES, J.A.M.A., SANCHEZ, M., SANTOS, F.A.M., PEDRONI, F., PEREIRA, L.S., PADGURSCHI, M.C., PRATA, E.M.B., RAMOS, E., TORRES, R.B., ROCHELLE, A.L.C., MARTINS, F.R, ALVES, L.F., VIEIRA, S.A., MARTINELLI, L.A., CAMARGO, P.B., SIMÕES, E., VILLANI, J.P. \& BELINELLO, R. no prelo. Florística e fitossociologia do componente arbóreo da Mata Atlântica ao longo do gradiente altitudinal dos Núcleos Picinguaba e Santa Virgínia/PESM, do sudeste do Brasil. Biota Neotrop. 11(2).

KÖEPPEN, W. 1948. Climatologia. Fondo de Cultura Econômica, Buenos Aires.

MANTOVANI W., LEITÃO FILHO, H.F. \& MARTINS, F.R. 1985. Chave baseada em caracteres vegetativos para identificacão de espécies lenhosas do cerrado da Reserva Biológica de Moji Guaçu, Estado de São Paulo. Hoehnea 12:35-56.

RADFORD, A.E., DICKISON, W.C., MASSEY, J.R. \& BELL, C.R. 1974 Vascular plant systematics. Harper \& Row, New York.
RAMOS, E. 2008. Estudos florísticos e fitossociológicos em trecho da Mata Atlântica (Ubatuba, SP) como subsídio para a conservação de recursos fitogenéticos. Dissertação de Mestrado, Instituto Agronômico, Campinas. http://www.iac.sp.gov.br/PosIAC/pdf/pb1210606.pdf

RAMOS, E., TORRES, R.B., VEIGA, R.F.A. \& JOLY, C.A. 2011. Estudo do componente arbóreo de trechos da Floresta Ombrófila Densa Submontana em Ubatuba (SP). Biota Neotrop.11(2): http://www.biotaneotropica.org. $\mathrm{br} / \mathrm{v} 11 \mathrm{n} 2 / \mathrm{pt} /$ abstract?inventory+bn02411022011

TALORA, D.C.; MORELLATO, P.C. 2000. Fenologia de espécies arbóreas em florestas de planície litorânea do sudeste do Brasil. Rev. Bra. Bot. 23(1):13-26.

URBANETZ, C.; TAMASHIRO, J. Y. \& KINOSHITA, L. S. 2010. Chave de identificação de espécies lenhosas de um trecho de Floresta Ombrófila Densa Atlântica, no Sudeste do Brasil, baseada em caracteres vegetativos. Biota Neotrop. 10(2): http://www.biotaneotropica.org.br/v10n2/pt/ abstract?article+bn00910022010 (último acesso em 15/12/2009).

VELOSO, H.P., RANGEL FILHO, A.L.R. \& LIMA, J.C.A. 1991. Classificação da vegetação brasileira, adaptada a um sistema universal. Rio de Janeiro: IBGE/DRNEA.

VIDAL, W.N. \& VIDAL, M.R.R. 2000. Botânica - organografia: quadros sinóticos ilustrados de fanerógamos. Universidade Federal de Viçosa, Viçosa. 


\section{Chave de identificação}

Baseada em caracteres vegetativos, para árvores, palmeiras e fetos arborescentes com pelo menos $15 \mathrm{~cm}$ de PAP, amostrados aos $100 \mathrm{~m}$ (Fazenda Capricórnio) e aos $200 \mathrm{~m}$ de altitude (PESM), em Ubatuba (SP)

1. Plantas com caule sem ramificações, folhas compostas Chave 1

(Arecaceae; Cyatheaceae)

2. Plantas com caule ramificado na porção aérea, folhas compostas

Chave 2

(Araliaceae; Bignoniaceae; Burseraceae; Caricaceae; Fabaceae; Malvaceae; Meliaceae; Sapindaceae)

3. Plantas com caule ramificado na porção aérea, folhas simples, opostas ou subopostas.

Chave 3

(Apocynaceae; Asteraceae; Boraginaceae; Celastraceae; Clusiaceae; Elaeocarpaceae; Lamiaceae; Melastomataceae; Monimiaceae; Myrtaceae; Nyctaginaceae; Quiinaceae; Rubiaceae; Siparunaceae; Verbenaceae)

4. Plantas com caule ramificado na porção aérea, folhas simples, alternas

Chave 4

(Annonaceae; Aquifoliaceae; Asteraceae; Araliaceae; Boraginaceae; Cardiopteridaceae; Celastraceae; Chrysobalanaceae; Combretaceae; Elaeocarpaceae; Euphorbiaceae; Fabaceae; Lauraceae; Lecythidaceae; Malvaceae; Magnoliaceae; Moraceae; Myristicaceae; Myrsinaceae; Nyctaginaceae; Ochnaceae; Olacaceae; Phyllanthaceae; Phytolaccaceae; Piperaceae; Polygonaceae; Salicaceae; Sapotaceae; Solanaceae; Symplocaceae; Thymeleaceae; Urticaceae)

Chave 1 - Plantas com caule sem ramificações, folhas compostas

1. Fetos arborescentes, frondes tripinatipartidas.

1'. Palmeiras, folhas pinadas .....

2. Pínulas com margem recortada.....

Cyathea hirsuta

2'. Pínulas com margem inteira 3

3. Escamas até $1,5 \times 0,1 \mathrm{~cm}$, conferindo aspecto lanoso à base do pecíolo Alsophila sternbergii

3'. Escamas ca. $2,5 \times 0,4 \mathrm{~cm}$, na base do pecíolo

Cyathea phalerata

4. Plantas com espinhos no caule e folhas Astrocaryum aculeatissimum

4'. Plantas inermes

5. Pinas não agrupadas ao longo da raque

Euterpe edulis

5'. Pinas distribuídas em grupos de 2-4 ao longo da raque

Syagrus pseudococos

Chave 2 - Plantas com caule ramificado na porção aérea, folhas compostas

1. Plantas armadas.

1'. Plantas inermes 4

2. Folhas digitadas Jacaratia spinosa

2'. Folhas pinadas ou bipinadas 3

3. Folhas bipinadas, folíolos rômbicos, margem inteira, sem pontuações

Pseudopiptadenia leptostachya

3'. Folhas pinadas, folíolos oblongo-elípticos ou elípticos, margem crenada, pontuações translúcidas Zanthoxylum fagara

4. Folhas 2-3 folioladas..... 5

4. Folhas com pelo menos 4 folíolos 6

5. Folhas 2-folioladas

Hymenaea courbaril var. altissima

5'. Folhas 3-folioladas Allophylus petiolulatus

6. Folhas digitadas 7

6'. Folhas não digitadas

7. Folíolos 5, margem serreada ou serrada Tabebuia serratifolia

7'. Folíolos 6 ou mais, margem inteira 8

8. Folíolos 6-9

Eriotheca pentaphylla 
8'. Folíolos 9 ou mais

9. Folíolos discolores, face abaxial ocráceo-velutina

..Schefflera angustissima

9'. Folíolos concolores, tricomas esparsos nas duas faces

Schefflera calva

10. Folhas bipinadas

10'. Folhas pinadas

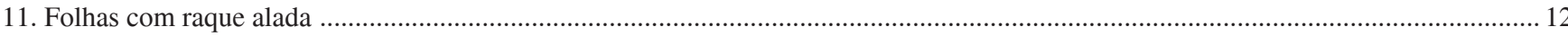

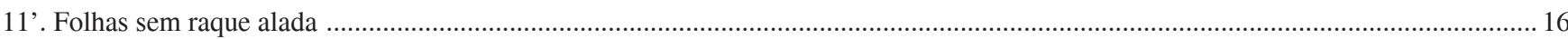

12. Ausência de nectários extra-florais

Swartzia langsdorfii

12'. Nectários extra-florais ao longo da raque nas intersecções dos peciólulos ...............................................................................13

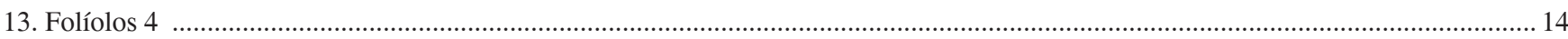

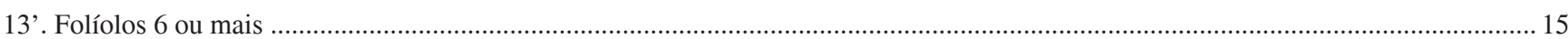

14. Raque das folhas estreito-alada por todo o comprimento, base dos folíolos atenuada, 6-9 pares de nervuras secundárias

Inga capitata

14'. Raque das folhas estreito-alada expandindo-se para o ápice, base dos folíolos cuneada, 4-6 pares de nervuras secundárias

Inga marginata

15. Folíolos ferrugíneo-tomentulosos nas duas faces, 15 pares de nervuras secundárias

Inga edulis

15'. Folíolos glabrescentes, até 12 pares de nervuras secundárias Inga grazielae

16. Folíolos alternos 17

16'. Folíolos opostos ou subopostos 21

17. Folíolos com pontuações translúcidas, numerosas, dispersas por toda a lâmina, visíveis contra a luz Myrocarpus frondosus

17'. Folíolos sem pontuações. 18

18. Folíolos obovais, ápice arredondado às vezes emarginado, margem irregularmente denteada no terço superior

Cupania oblongifolia

18'. Folíolos elípticos a oblongo-elípticos, margem inteira

19

19. Raque das folhas sem gema terminal ou prolongamento semelhante a um folíolo atrofiado...... Pterocarpus rohrii

19'. Raque das folhas com gema terminal ou prolongamento semelhante a um folíolo atrofiado 20

20. Raque das folhas com gema terminal, folíolos $11 \times 3,5 \mathrm{~cm}$

Guarea macrophylla

20'. Raque das folhas com prolongamento semelhante a um folíolo atrofiado e oposto ao folíolo terminal, folíolos $20 \times 6 \mathrm{~cm}$ Matayba intermedia

21. Folíolos com pontuações translúcidas, numerosas, dispersas por toda a lâmina, visíveis contra luz. Copaifera langsdorfii

21'. Folíolos sem pontuações 22

22. Folíolos com domácias ferrugíneo-tomentosas nas axilas da nervura central 23

22’. Folíolos sem domácias

23. Folíolos com margem profundamente serrada, indumento ferrugíneo na face abaxial

Cupania furfuracea

23'. Folíolos com margem inteira, glabrescentes

Cabralea canjerana

24. Folíolos ovados ou elíptico-oblongos, ápice abruptamente caudado, ca. $20 \times 8 \mathrm{~cm}$ Dahlstedtia pinnata

24’. Folíolos oblongos, elípticos ou elíptico-rômbicos, até $17 \times 4,5 \mathrm{~cm}$

25. Folíolos oblongos, 15-18 pares de nervuras secundárias

Swartzia oblata

25'. Folíolos elípticos ou elíptico-rômbicos, até 12 pares de nervuras secundárias .26

26. Peciólulos 1,5-4,5 cm compr., folíolos 5

Protium kleinii

26'. Peciólulos até $1 \mathrm{~cm}$ compr., folíolos 6 ou mais 27

27. Peciólulos 0,3 cm compr., folíolos membranáceos.

.Lonchocarpus cultratus

27’. Peciólulos 1 cm compr., folíolos cartáceos a subcoriáceos. 
Chave 3 - Plantas com caule ramificado na porção aérea, folhas simples, opostas ou subopostas

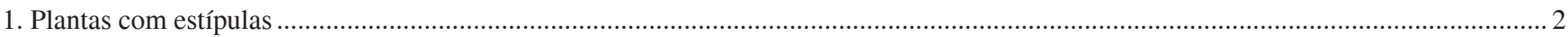

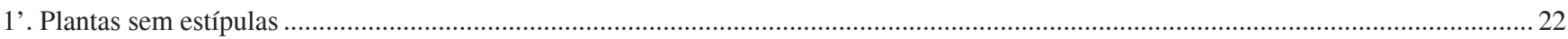

2. Pecíolos espessados na base e no ápice, folhas opostas e subopostas

Sloanea guianensis

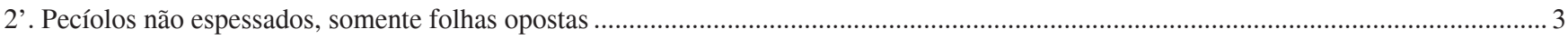

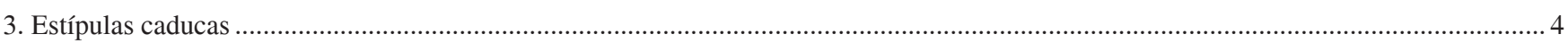

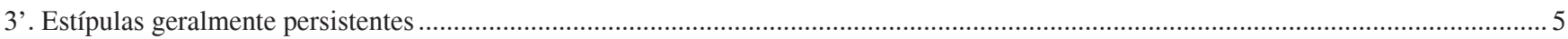

4. Pecíolos 0,5 cm larg., lâmina com pelo menos $23 \times 10,5 \mathrm{~cm}$..

Salacia grandifolia

4'. Pecíolos 0,2 cm larg., lâmina até $17 \times 7,5 \mathrm{~cm}$

Tontelea aff. fluminensis

5. Estípulas foliáceas

Quiina glaziovii

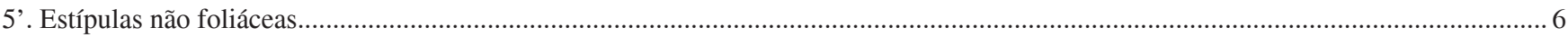

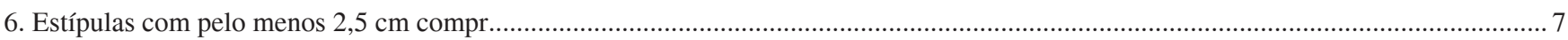

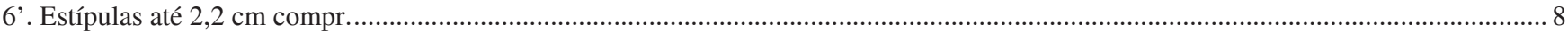

7. Extremidade dos ramos quadrangular, pecíolos $7 \mathrm{~cm}$ compr., folhas denso-tomentulosas na face abaxial, sem pontuações

Bathysa australis

7’. Extremidade dos ramos cilíndrica, pecíolos até $3 \mathrm{~cm}$ compr., folhas tomentulosas a glabrescentes na face abaxial, com pontuações translúcidas

Rustia formosa

8. Estípulas triangulares ou lanceoladas . .9

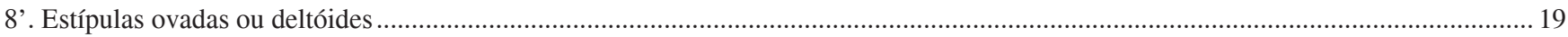

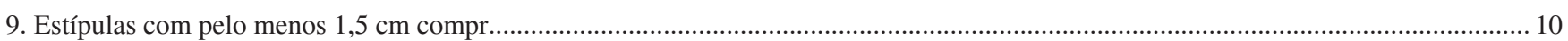

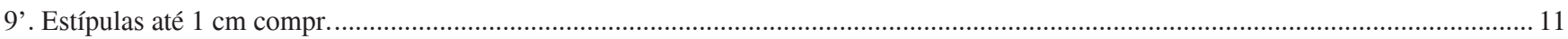

10. Extremidade dos ramos cilíndrica, folhas elípticas, com domácias.

Bathysa mendoncaei

10'. Extremidade dos ramos quadrangular, folhas amplo-elípticas, sem domácias

Bathysa stipulata

11 Folhas com domácias na face abaxial

11'. Folhas sem domácias

12. Domácias em fenda

Coussarea meridionalis var. porophylla

12'. Domácias com tricomas.

13. Folhas com 7 pares de nervuras secundárias

Randia sp. 1

13'. Folhas com 4-5 pares de nervuras secundárias

Randia sp. 2

14. Folhas concentradas no ápice dos ramos

Alseis floribunda

14'. Folhas não concentradas no ápice dos ramos

15

15. Gema apical glabra, extremidade dos ramos nigrescente no material seco......

Faramea pachyantha

15'. Gema apical com tricomas, extremidade dos ramos não nigrescente no material seco ..... 16

16. Estípulas bífidas

16'. Estípulas inteiras.

18

17. Nervuras secundárias conspícuas na face abaxial, geralmente discolores no material seco

Psychotria birotula

17'. Nervuras secundárias pouco conspícuas na face abaxial, concolores no material seco Psychotria nuda

18. Folhas com ápice agudo a acuminado, venação terciária formando retículos conspícuos

Coutarea hexandra

18'. Folhas com ápice abrupto-longo-acuminado, às vezes falcado, venação terciária inconspícua.

cf. Chomelia sp.

19. Estípulas com apêndice terminal denticulado

Rudgea jasminoides

19'. Estípulas sem apêndice terminal.

20. Estípulas deltóides

Posoqueria latifolia

20’. Estípulas ovadas 
21. Estípulas ovadas, membranáceas, folhas com ápice abrupto-acuminado a caudado, 8-10 pares de nervuras secundárias

21'. Estípulas amplo-ovadas, crassas, folhas com ápice arredondado, às vezes agudo, 15-18 pares de nervuras secundárias

Rudgea vellerea

22. Folhas opostas e subopostas (às vezes até alternas espiraladas) 23

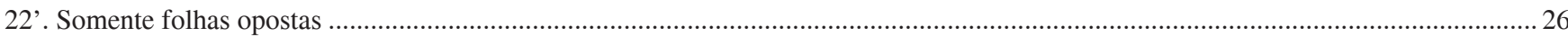

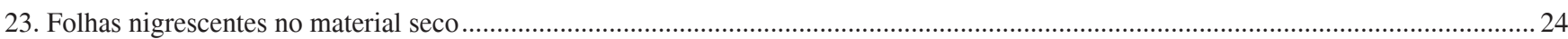

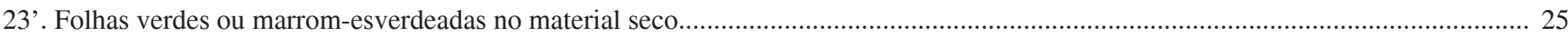

24. Pecíolos até $0,6 \mathrm{~cm}$ compr., lâmina até $7,5 \mathrm{~cm}$ compr..

Guapira hirsuta

24'. Pecíolos com pelo menos 3,5 cm compr., lâmina até $30 \mathrm{~cm}$ compr

..Guapira opposita

25. Folhas com 4-6 pares de nervuras secundárias, pontuações amarronzadas esparsas na face abaxial, visíveis com auxílio de lupa

Cordia cf. superba

25'. Folhas com 8 pares de nervuras secundárias, sem pontuações.

Cordia taguahyensis

26. Venação acródroma .27

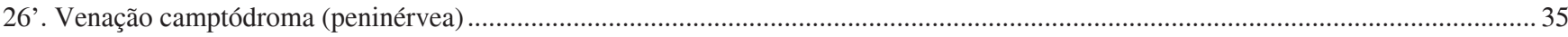

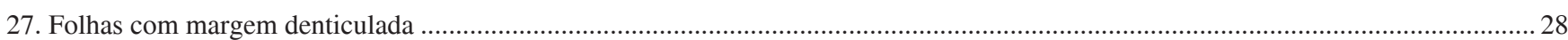

27'. Folhas com margem inteira

31

28. Margem mucronulada Miconia tristis subsp. australis

28'. Margem não mucronulada .29

29. Folhas com tricomas simples e estrigosos na face adaxial

Leandra dasytricha

29'. Folhas glabras na face adaxial 30

30. Folhas glabras

Meriania calyptrata

30'. Folhas glabras na face adaxial, diminuto esparso-estreladas a glabrescentes na abaxial Miconia cf. picinguabensis

31. Folhas glabras ou glabrescentes, tricomas simples 32

31'. Folhas com tricomas estrelados ou lepidotos

32. Pecíolos com pelo menos 4,5 cm compr., folhas elíptico-ovais, membranáceas a subcartáceas

Henriettella glabra

32'. Pecíolos até $2,5 \mathrm{~cm}$ compr., folhas elípticas, cartáceas a subcoriáceas Miconia cinnamomifolia

33. Pecíolos com pelo menos 7,5 cm compr., folhas amplo-elípticas . Miconia cabucu

33'. Pecíolos até 5,5 cm compr., folhas elípicas, elíptico-obovais ou elíptico-ovais 34

34. Folhas s enegrecidas quando secas, concolores, tricomas lepidotos Miconia sp. 3

34'. Folhas marrom-esverdeadas quando secas, discolores, tricomas denso-estrelados Miconia dodecandra

35. Plantas latescentes. 36

35'. Plantas não latescentes... 37

36. Extremidade dos ramos nigrescente no material seco, folhas com 5-8 pares de nervuras secundárias Malouetia arborea

36'. Extremidade dos ramos não nigrescente no material seco, folhas com ca. 20 pares de nervuras secundárias, paralelas, canais resiníferos conspícuos na face abaxial

Garcinia gardneriana

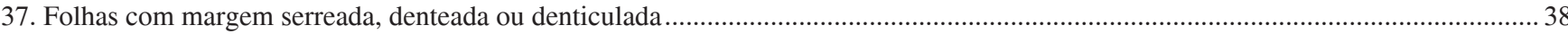

37'. Folhas com margem inteira

38. Folhas concentradas no ápice dos ramos

Vernonia sp.

38'. Folhas não concentradas no ápice dos ramos

39. Pecíolo pelo menos $2,5 \mathrm{~cm}$ compr., folhas com base truncada, margem denticulada, tricomas estrelados

Siparuna brasiliensis

39'. Pecíolo até 1,5cm compr., folhas com base atenuada ou cuneada, margem serreada, tomentosa a glabrescente

40

40. Folhas denso-tomentosas

Mollinedia lamprophylla 
40'. Folhas tomentosas a glabrescentes

41. Folhas estreito-elípticas, falcadas, até $9,5 \mathrm{~cm}$ compr

Mollinedia uleana

41’. Folhas elípticas a amplo-elípticas, maiores que 9,5 cm compr.

42. Folhas com ápice agudo

Mollinedia oligantha

42’. Folhas com ápice acuminado.

43. Folhas elípticas a obovais, ápice curto-acuminado

Mollinedia schottiana

43'. Folhas elípticas a elíptico-oblongas, às vezes ovais, ápice estreito-acuminado

Mollinedia boracensis

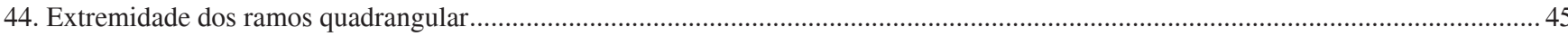

44'. Extremidade dos ramos cilíndrica ou achatada ..... 46

45. Pecíolos com pelo menos 4,5 cm compr., com um par de glândulas cimbiformes no ápice ou na base

Citharexylum myrianthum

45'. Pecíolos com até $2 \mathrm{~cm}$ compr., sem glândulas Aegiphila integrifolia

46. Folhas sem pontuações

Mouriri chamisoana

46'. Folhas com pontuações. 47

47. Folhas com pontuações opacas . 48

47'. Folhas com pontuações translúcidas. 56

48. Nervuras secundárias anastomosadas em arcos conspícuos afastados da margem, ausência de nervura marginal verdadeira................ 49

48'. Nervuras secundárias anastomosadas próximo à margem, não arqueadas, presença de nervura marginal verdadeira.

49. Folhas ovadas, ápice agudo, base cuneada, assimétrica, pontuações vináceas na face abaxial

Campomanesia guaviroba

49’. Folhas elípticas, ápice acuminado, base atenuada, pontuações hialinas na face abaxial Campomanesia laurifolia

50. Anisofilia na extremidade dos ramos, no mesmo nó

Calyptranthes lanceolata

50’. Extremidade dos ramos sem essa característica

51

51. Folhas com tricomas reluzentes na face abaxial

Eugenia batingabranca

51'. Folhas glabras, glabrescentes ou com tricomas não reluzentes na face abaxial. 52

52. Lâminas até $10 \mathrm{~cm}$ compr. 53

52'. Lâminas maior que $10 \mathrm{~cm}$ compr.

53. Nervura central plana na face adaxial, secundárias espaçadas ca. $0,7 \mathrm{~cm}$ Eugeniaprasina, Eugenia cf.subavenia 53'. Nervura central imersa na face adaxial, secundárias espaçadas $0,1 \mathrm{~cm}$ Myrciaria floribunda

54'. Folhas elípticas a oblongo-elípticas a obovais, até $16 \mathrm{~cm}$ compr., base atenuada, glaucas quando secas Eugenia mosenii

54'. Folhas oblongas ou ovais, maiores que $17 \mathrm{~cm}$ compr., base cuneada a truncada a arredondada, amarronzadas quando secas 55

55. Folhas com pelo menos $27 \mathrm{~cm}$ compr., 25-40 pares de nervuras secundárias espaçadas ca. $1 \mathrm{~cm}$ Marlierea glazioviana

55'. Folhas até $22 \mathrm{~cm}$ compr., 8-11 pares de nervuras secundárias espaçadas ca. $2 \mathrm{~cm}$ Calyptranthes grandifolia

56. Folhas sub-sésseis (pecíolos até $0,3 \mathrm{~cm}$ compr.)

56 '. Folhas com pecíolos evidentes (maiores que $0,5 \mathrm{~cm}$ compr.) .58

57. Folhas oval-elípticas ou elíptico-oblongas, até $17 \mathrm{~cm}$ compr., venação secundária inconspícua

Eugenia monosperma

57'. Folhas elípticas a elíptico-obovais, até 37 cm compr., ca. 20 pares de nervuras secundárias

Myrcia spectabilis

58. Pecíolos até $0,9 \mathrm{~cm}$ compr.

58'. Pecíolos iguais ou maiores $1 \mathrm{~cm}$ compr.

59. Folhas até $5,5 \mathrm{~cm}$ compr.

Marlierea suaveolens

59'. Folhas maiores que $8,5 \mathrm{~cm}$ compr.

60. Folhas oblongas a oblongo-elípticas

Calyptranthes strigipes

60 '. Folhas elípticas ou ovais.

61

61. Lâminas 18-25 cm compr. Myrcia sp. 1 
61'. Lâminas até $13 \mathrm{~cm}$ compr 62

62. Extremidade dos ramos ferrugíneo-tomentosa

62'. Extremidade dos ramos dourado ou amarelado-tomentulosa a glabrescente

63. Folhas com ápice acuminado, nervura marginal conspícua.

Myrceugenia myrcioides

63'. Folhas com ápice longo-acuminado, nervura marginal inconspícua....

64. Folhas elípticas a oboval-elípticas, ápice acuminado a longo-acuminado

Eugenia cf. supraaxilaris

64'. Folhas estreito-elípticas, ápice longo acuminado, estreito

Eugenia cuprea

65. Extremidade dos ramos ferrugíneo-lanosa.....

Marlierea sylvatica

65'. Extremidade dos ramos dourado-tomentosa ou glabrescente a glabra

66

66. Extremidade dos ramos dourado-tomentosa

Myrcia pubipetala

66'. Extremidade dos ramos glabrescente a glabra.

67. Nervuras secundárias conspícuas (proeminentes) na face abaxial 68

67'. Nervuras secundárias pouco conspícuas

68. Folhas com ápice agudo, ca. 12 pares de nervuras secundárias.

Eugenia cf. bocainensis

68'. Folhas com ápice abrupto-acuminado, ca. 28 pares de nervuras secundárias Marlierea tomentosa

69. Folhas amplo-elípticas Eugenia cerasiflora

69'. Folhas elípticas, ovais, oblongas ou obovais.... .70

70. Folhas obovais, oboval-elípticas ou amplo-elípticas . .71

70'. Folhas elípticas, ovais, oblongas, ou oblongo-elípticas.. .73

71. Folhas com ápice agudo. Eugenia involucrata

71'. Folhas com ápice abrupto-acuminado a caudado 72

72. Folhas com ca. 20 pares de nervuras secundárias.

Neomitranthes glomerata

72'. Folhas com ca. 10 pares de nervuras secundárias Eugenia cf. excelsa

73. Folhas com ápice agudo-arredondado Eugenia cf. multicostata

73'. Folhas com ápice acuminado a longo-acuminado-caudado .74

74. Nervuras secundárias espaçadas ca. $0,5 \mathrm{~cm}$. .75

74'. Nervuras secundárias espaçadas 0,7-1 cm 78

75. Folhas com ca. 11 pares de nervuras secundárias.....

Eugenia neoautralis

75'. Folhas com 20-30 pares de nervuras secundárias .76

76'. Folhas com mais de 30 pares de nervuras secundárias

Marlierea racemosa

76. Folhas com ca. 20 pares de nervuras secundárias .77

77. Face adaxial das folhas glauca no material seco

Calyptranthes cf. lucida

$77^{\prime}$. Face adaxial das folhas não glauca no material seco.

Eugenia tinguyenis

78. Folhas com 10-12 pares de nervuras secundárias

Eugenia oblongata, Eugenia aff. oblongata

78'. Folhas com 14-16 pares de nervuras secundárias

Myrcia sp. 2

Chave 4 - Plantas com caule ramificado na porção aérea, folhas simples, alternas

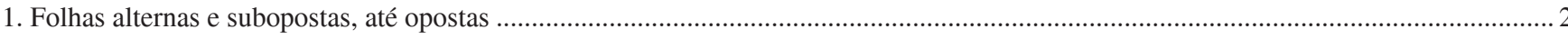

1 '. Somente folhas alternas

2. Pecíolos espessados na base e no ápice 6

2'. Pecíolos não espessados

3. Folhas nigrescentes no material seco

3'. Folhas verdes ou marrom-esverdeadas no material seco. 
4. Pecíolos até $0,6 \mathrm{~cm}$ compr., lâmina até $7,5 \mathrm{~cm}$ compr..

Guapira cf. hirsuta

4'. Pecíolos com pelo menos 3,5 cm compr., lâmina até $30 \mathrm{~cm}$ compr.

Guapira opposita

5. Folhas com 4-6 pares de nervuras secundárias, pontuações amarronzadas esparsas na face abaxial, visíveis com auxílio de lupa

Cordia cf. superba

5'. Folhas com 8 pares de nervuras secundárias, sem pontuações

Cordia taguahyensis

6. Plantas com estípulas

6’. Plantas sem estípulas

7. Folhas digitilobadas

7'. Folhas não lobadas.....

8. Folhas 3-5 lobadas .

Pourouma guianensis

8'. Folhas com mais de 6 lobos.

9. Folhas discolores, face abaxial esbranquiçada, nervuras esbranquiçadas

Cecropia pachystachya

9'. Folhas levemente discolores, face abaxial esverdeada, nervuras vermelhas.

Cecropia glaziovii

10. Folhas com margem recortada (de crenulada até espinescente).

10'. Folhas com margem inteira

11. Folhas com venação actinódroma basal.

11'. Folhas com venação camptódroma (peninérvea)

12. Plantas com tricomas simples, estrigosos

Urera baccifera

12'. Plantas com tricomas estrelados

13. Folhas elíptico-ovais, ápice acuminado a cuspidado, glabrescentes, face adaxial glauca no material seco, 4 pares de nervuras secundárias.

Alchornea triplinervia

13'. Folhas orbiculares

14. Folhas com ápice acuminado, face abaxial esparso-estrelada, 5 pares de nervuras secundárias

Alchornea glandulosa

14’. Folhas com ápice obtuso a arredondado, face abaxial estrelado-lanosa ou denso-estrelada, 6-7 pares de nervuras secundárias.

Alchornea sidifolia

15. Pecíolos com duas glândulas na porção distal

15'. Pecíolos sem glândulas

16. Pecíolos com glândulas discóides no ápice, folhas elípticas ou ovais, margem irregular-dentada, até 7 pares de nervuras secundárias.....

Tetrorchidium rubrivenium

16'. Pecíolos com glândulas alongadas no ápice

17. Folhas obovais, margem glandular-serrada, mais evidente a partir do terço inferior, 16-19 pares de nervuras secundárias, paralelas, conspícuas, venação terciária paralela.

.Pausandra morisiana

17'. Folhas oblongas a oboval-elípticas, margem denticulada, com glândulas conspícuas, esparsas, (6-) 7-16 pares de nervuras secundárias, venação terciária reticulada

Sapium glandulosum

18. Folhas com margem espinescente.

18'. Folhas com margem sem espinhos

19. Folhas oblongas a oblongo-elípticas, ápice abrupto-longo-acuminado, mucronado, base assimétrica, margem irregular-esparsoespinescente.....

..Sorocea hilarii

19’. Folhas elíptico-oblongas, ápice agudo, base arredondado-truncada, margem regular-espinescente

Zollernia ilicifolia

20. Plantas com látex conspícuo

20’. Plantas sem látex

21. Folhas elípticas, ou oboval-elípticas, base assimétrica, margem espaçadamente glandular-crenada a partir do terço superior

Brosimum lactescens

21'. Folhas oblongas, base cuneada, margem serreada

Mabea piriri

22. Folhas com margem crenulada ou serreada 
22'. Folhas com margem serrulada.....

23. Folhas com base atenuada, 8-11 × 3-4 cm, margem crenulada, membranáceas, 7-9 pares de nervuras secundárias

Maytenus robusta

23'. Folhas com base cuneada, $14 \times 5,5 \mathrm{~cm}$, margem serreada, coriáceas, 12 pares de nervuras secundárias Maytenus sp. 1

24. Folhas com glândulas translúcidas. Casearia sylvestris

24'. Folhas sem glândulas translúcidas

25. Folhas com base cuneada, venação terciária paralela e perpendicular à nervura principal

Cariniana estrellensis

25’. Folhas com base decurrente, revoluta, venação terciária paralela à secundária

Lecythis cf. lanceolata

26. Ramos com nós geniculados

26'. Ramos sem nós geniculados

27. Folhas com base fortemente caudada-auriculada, assimétrica, lâmina maior que $30 \mathrm{~cm}$ compr.

Piper cernuum

27'. Folhas com base assimétrica, lâmina menor que $21 \mathrm{~cm}$ compr.

28

28. Pecíolos até $0,8 \mathrm{~cm}$ compr., folhas elípticas ou ovadas, até $8 \mathrm{~cm}$ larg., ásperas ao toque

Piper gaudichaudianum

28'. Pecíolos até $2 \mathrm{~cm}$ compr., folhas oval-elípticas, com pelo menos $10 \mathrm{~cm}$ larg., macias ao toque Piper rivinoides

29. Ramos ocos, com ócrea Coccoloba glaziovii

29’. Ramos maciços, sem ócrea..... 30

30. Estípulas terminais conspícuas 31

30’. Estípulas terminais inconspícuas .34

31. Plantas sem látex, pecíolos curto-alados. Magnolia ovata

31'. Plantas com látex, pecíolos não alados 32

32. Folhas com manchas avermelhadas no limbo, ramos e pecíolos escamantes. Ficus pulchella

32'. Folhas sem essas características 33

33. Espaçamento entre as nervuras secundárias a. $1 \mathrm{~cm}$, venação terciária inconspícua Ficus insipida

33'. Espaçamento entre nervuras secundárias e terciárias ca. $0,5 \mathrm{~cm}$, conspícuas

Ficus obtusiuscula

34. Venação actinódroma.

Coussapoa microcarpa

34'. Venação camptódroma ou craspedódroma. 35

35. Folhas com tricomas lepidotos...... 36

35'. Folhas glabras ou com com tricomas simples 37

36. Folhas elípticas a elíptico-obovais, ápice acuminado

36'. Folhas ovado-orbiculares a ovado-elípticas, ápice agudo ou curto-acuminado

Hieronyma alchorneides

37. Folhas com indumento pardo ou ferrugíneo, adensado 38

37'. Folhas glabras ou glabrescentes

38. Folhas com tricomas ferrugíneos 39

38'. Folhas com tricomas pardos

39. Folhas oblongo-elípticas a obovais, 30 pares de nervuras secundárias paralelas, espaçadas ca. $1 \mathrm{~cm}$, face abaxial ferrugíneo-lanuginosa, sem glândulas na base.

Ecclinusa ramiflora

39'. Folhas elípticas a elíptico-oblongas, 13 pares de nervuras secundárias paralelas, espaçadas até $2 \mathrm{~cm}$, face abaxial da lâmina ferrugíneopubescente, um par de glândulas na base, visível com auxílio de lupa

Hirtella hebeclado

40. Folhas em geral oblongas, lâmina com $18,5 \times 6 \mathrm{~cm}$, até 13 pares de nervuras secundárias, paralelas, espaçadas ca. $1,5 \mathrm{~cm}$

Couepia venosa

40’. Folhas em geral elípticas, lâmina com $12 \times 3 \mathrm{~cm}$, até 7 pares de nervuras secundárias, paralelas, espaçadas $0,5-1 \mathrm{~cm}$

Licania hoehnei

41. Pecíolos menores que $1 \mathrm{~cm}$, lâmina até $10,5 \mathrm{~cm}$ compr.

Ouratea parvifolia

41'. Pecíolos maiores ou igual que $1 \mathrm{~cm}$, lâmina maiores ou iguais a $15 \mathrm{~cm}$ compr.

42

42. Pecíolos até $7 \mathrm{~cm}$ compr., com extremidades espessadas 
42'. Pecíolos 1-2 cm compr., sem extremidades espessadas

43. Extremidade dos ramos achatada, protuberâncias diminutas, numerosas, dispersas por toda a lâmina, visíveis com auxílio de lupa......... Maytenus ubatubensis

43'. Extremidade dos ramos levemente quadrangular ou cilíndrica

44. Extremidade dos ramos levemente quadrangular, folhas obovais, ápice arredondado, lâmina com $15 \mathrm{~cm}$ compr., 7 pares de nervuras secundárias

Ilex theezans

44'. Extremidade dos ramos cilíndrica, folhas oblongo-elípticas, ápice acuminado, lâmina com $24 \mathrm{~cm}$ compr., 9-11 pares de nervuras secundárias.

Indeterminada sp. 1

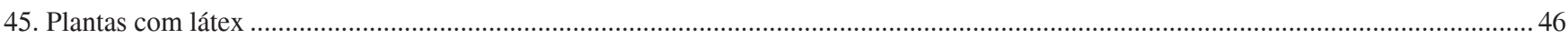

45'. Plantas sem látex

46. Látex vermelho

46'. Látex branco

47. Folhas não concentradas no ápice dos ramos

47'. Folhas concentradas no ápice dos ramos

48. Folhas geralmente obovais, nervuras secundárias numerosas, espaçadas ca. $0,2 \mathrm{~cm}$

Micropholis crassipedicellata

48'. Folhas elípticas ou oblongas, 7 pares de nervuras secundárias

49. Pecíolos até $1,3 \mathrm{~cm}$ compr., folhas dísticas

Chrysophyllum flexuosum

49'. Pecíolos pelo menos $2 \mathrm{~cm}$ compr., espessados na base, folhas espiraladas

Pouteria sp. 1

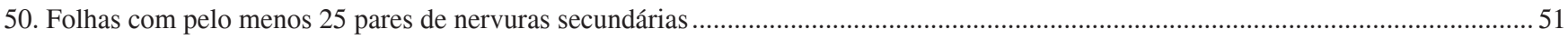

50'. Folhas com até 18 pares de nervuras secundárias

51. Pecíolos até $1 \mathrm{~cm}$ compr., folhas discolores, face abaxial dourado-serícea

Pouteria aff. torta

51'. Pecíolos pelo menos $2 \mathrm{~cm}$ compr., folhas concolores, face abaxial tomentulosa

Pouteria sp. 2

52. Folhas oblongas, pelo menos 12 pares de nervuras secundárias

Pouteria caimito

52'. Folhas obovadas, até 11 pares de nervuras secundárias

Pouteria psammophila

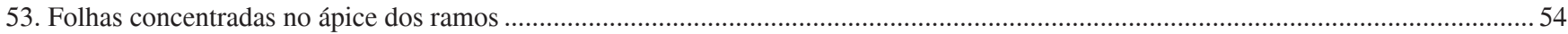

53'. Folhas não concentradas no ápice dos ramos .

.55

54. Folhas obovais, ápice arredondado a agudo, lâmina até $12 \mathrm{~cm}$ compr., até 6 pares de nervuras secundárias

Buchenavia kleinii

54. Folhas em geral elípticas, ápice acuminado, lâmina com pelo menos $16 \mathrm{~cm}$ compr., ca. 11 pares de nervuras secundárias

Terminalia januariensis

55. Venação actinódroma (trinérvea)

Tetrastylidium grandifolium

55'. Venação camptódroma (peninérvea)

.56

56. Folhas com domácias puntifomes na face abaxial

Citronella paniculata

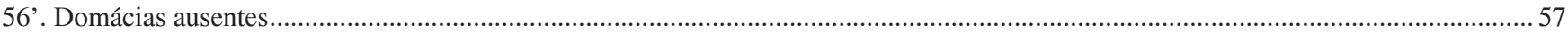

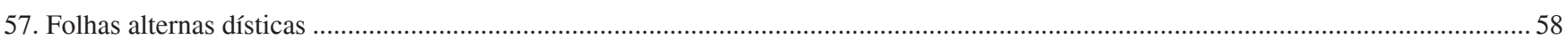

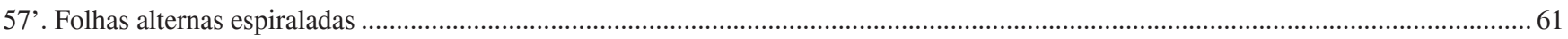

58. Extremidade dos ramos e face abaxial das folhas lanoso-ferrugíneas.

Rollinia dolabripetala

58 '. Extremidade dos ramos e face abaxial das folhas glabrescentes ou glabras

59. Pecíolos 0,5 cm compr.

Guatteria australis

59'. Pecíolos pelo menos $1 \mathrm{~cm}$ compr.

60. Extremidade dos ramos em zigue-zague, folhas com margem inteira, 15-20 nervuras secundárias, paralelas

Heisteria silvianii

60'. Extremidade dos ramos reta, folhas com margem irregularmente denteada a partir da metade superior, 6 pares de nervuras secundárias Symplocos variabilis

61. Folhas com tricomas estrelados, lepidotos ou peltados ..... 62

61'. Folhas com tricomas simples, glabrescentes ou glabras 
62. Folhas com tricomas estrelados 63

62'. Folhas com tricomas simples ou lepidotos.

63. Lâminas pelo menos $20 \mathrm{~cm}$ compr., até 10 pares de nervuras secundárias, face abaxial denso-estrelada, macia ao toque

Solanum cf. bullatum

63'. Lâminas até 17 cm compr., 5 pares de nervuras secundárias, face abaxial glabrescente, lisa ao toque Solanum sp. 1

64. Folhas discolores, margem inteira, tricomas lepidotos....

Solanum swartzianum

64'. Folhas concolores, margem diminuto-serreado-glandulosa, tricomas simples e lepidotos. Vernonia puberula

65. Folhas com pontuações, visíveis com auxílio de lupa 66

65'. Folhas sem pontuações .

66. Extremidade dos ramos ferrugíneo-velutina

Rapanea ferruginea

66'. Extremidade dos ramos glabra 67

67. Folhas com pontuações avermelhadas

Ardisia martiana

67'. Folhas com pontuações nigrescentes, canais secretores na base e sobre a nervura central.

Rapanea hermogenesii

68. Pecíolos $7 \mathrm{~cm}$ compr., lâmina com ráfides visíveis com auxílio de lupa..... Phytollaca dioica

68'. Pecíolos até $2 \mathrm{~cm}$ compr., lâmina sem ráfides

69. Extremidade dos ramos amarelo-lanosa

Ocotea tabacifolia

69'. Extremidade dos ramos glabra ou glabrescente 70

70. Folhas com face abaxial esbranquiçada ou glauca no material seco Cryptocarya saligna

70'. Folhas sem estas características 71

71. Nervuras secundárias ascendendo em ângulo agudo de aproximadamente $45^{\circ}$ em direção ao ápice, formando arcos inconspícuos....... 72

71'. Nervuras secundárias formando arcos conspícuos distantes da margem .73

72. Folhas elípticas, às vezes falcadas, ápice longo-acuminado ou caudado, 4-7 pares de nervuras secundárias

2’. Folhas elípticas ou ovais, ápice agudo, 3-4 pares de nervuras secundárias

Nectandra membranacea

73. Folhas em geral obovadas Endlicheria paniculata

73'. Folhas em geral elípticas, ovais ou oblongas 74

74. Lâminas com pelo menos 20,5 cm compr., ápice acuminado, ca. 10 pares de nervuras secundárias Daphnopsis schwackeana

74'. Lâminas até $13,5 \mathrm{~cm}$ compr., até 7 pares de nervuras secundárias .75

75. Lâminas até 13,5 cm compr., ápice acuminado, lanuginosas, até 7 pares de nervuras secundárias

Ocotea paranapiacabensis

75'. Lâminas até 8,5 cm compr., ápice abrupto-longo-acuminado, glabras, até 5 pares de nervuras secundárias Ocotea teleiandra

76. Folhas oblongas, oval-oblongas ou elítptico-oblongas .77

76 '. Folhas elípticas a oval-elípticas, às vezes falcadas. .79

77. Pecíolos pelo menos $2 \mathrm{~cm}$ compr.

Cryptocarya mandioccana

77'. Pecíolos até $1 \mathrm{~cm}$ compr. .78

78. Folhas com ápice longo-acuminado-falcado, 6-7 pares de nervuras secundárias Ocotea dispersa

78'. Folhas com ápice agudo a acuminado, ca. 12 pares de nervuras secundárias...... Indeterminada sp. 3

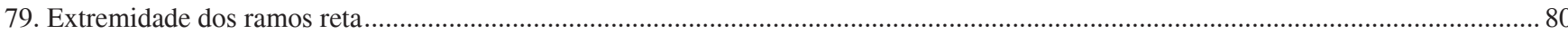

79'. Extremidade dos ramos em zigue-zague .81

80. Pecíolos achatados, concolores em relação ao limbo no material seco, folhas elípticas a oval-elípticas

Ocotea brachybotra

80’. Pecíolos cilíndricos, nigrescentes (discolores em relação ao limbo) no material seco, folhas elípticas a elíptico-falcadas

Licaria armeniaca

81. Folhas com base não revoluta, 4-5 pares de nervuras secundárias Indeterminada sp. 4

81’. Folhas s com base revoluta, ca. 10 pares de nervuras secundárias. Indeterminada sp. 2 